\title{
Integrated thematic geological mapping of the Atlantic Margin of Iberia
}

\author{
Pedro Terrinha ${ }^{1,2 *}$, Teresa Medialdea ${ }^{3}$, Luis Batista ${ }^{1,2}$, Luis Somoza $^{3}$, \\ Vitor Magalhães ${ }^{1,2}$, Francisco Javier González ${ }^{3}$, João Noiva ${ }^{1}$, Ana Lobato ${ }^{3}$, \\ Marcos Rosa $^{1}$, Egidio Marino ${ }^{3}$, Pedro Brito ${ }^{1,2}$, Marta Neres ${ }^{1,2}$ and \\ Carlos Ribeiro ${ }^{4}$ \\ ${ }^{1}$ IPMA, Instituto Português do Mar e da Atmosfera, Rua C do Aeroporto, 1749-077 Lisboa, \\ Portugal \\ ${ }^{2}$ IDL, Instituto Dom Luíz, University of Lisbon, FCUL, Campo Grande Edifício C1, 1749- \\ 016 Lisboa, Portugal \\ ${ }^{3}$ IGME, Instituto Geológico y Minero de España, Ríos Rosas, 23, 28003 Madrid, Spain \\ ${ }^{4}$ Department of Geociências, University of Évora; Instituto Ciências da Terra; Rua Romão \\ Ramalho, 59, 7000-671 Évora, Portugal
}

PT, 0000-0002-6824-6002; TM, 0000-0002-7969-5751; LB, 0000-0002-0830-1612; LS, 0000-0001-5451-2288; VM, 0000-0002-3205-771X; JN, 0000-0002-5625-3432;

EM, 0000-0001-9392-0647; MN, 0000-0003-3939-4636; CR, 0000-0001-7492-1425

*Correspondence: pedro.terrinha@ipma.pt

\begin{abstract}
This paper synthesizes the geology of the Atlantic Margin off the coast of Iberia and surrounding Abyssal Plains using published thematic mapping freely downloadable from EMODNET-Geology portal at different scales. Selected information was chosen in order to highlight mineral occurrences and natural hazards overlaid on geological and morphological maps. Altogether, this information is published and interpreted here for the first time; nevertheless this exercise can be carried out by anyone interested and allows different visualizations of geological objects. Cross-correlations of geological objects and processes can easily arise. Because all of the information (each piece of data and metadata) in the EMODNET-Geology portal has bibliographic references associated, readers are able to find the original source of information. It is shown that clicking in and out of layers of information (that cannot be found all together in a single scientific paper) allows quick cross-correlation using the EMODNET Geology thematic portal. This allows a free, versatile and quick way of cross-correlating geological objects and processes in vast marine areas and their comparison with onshore geology.
\end{abstract}

Iberia is a trapezoidal continental block located between stable Eurasia and NW continental Africa. The onshore geology of Iberia has a stratigraphic record spanning from terranes of Proterozoic age involved in the Paleozoic Wilson cycle through the Alpine Wilson cycle, from Triassic through Quaternary times. The Paleozoic cycle ended with the formation of Pangea during Permian times when Iberia was trapped at the westernmost tip of the Tethys Ocean between Laurasia and Gondwana (Nance et al. 2012; Terrinha et al. 2019a; Vergés et al. 2019 and references therein).

The Atlantic Margin of Iberia (Fig. 1) encompasses three different tectonic sectors, the West Iberia Margin (WIM), the North Iberia Margin (NIM) and the SW Iberia Margin (SWIM) that formed as a result of rifting and seafloor spreading of the North Atlantic Ocean, Bay of Biscay and Western Tethys Ocean (or Neo-Tethys), respectively. The
NIM and SWIM were strongly involved in continental collision and subduction during the Alpine orogeny and both abut two orogenic belts, the Pyrenees and the Betics, respectively in the north and south of the Iberia Peninsula. The Pyrenees resulted from continental collision between Iberia and stable Eurasia in Late Cretaceous-Paleogene times (Boillot and Capdevila 1977). The Betics formed as a result of a complex tectonic history of oceanic subduction of the Tethys Ocean, slab roll-back and formation of back-arc basins that ended with accretion of the Betic terranes in southern Spain (e.g. Maldonado et al. 1999; Schettino and Turco 2011; Vergés et al. 2019). The West Galicia Margin that experienced the rifting of the North Atlantic Ocean is described here together with the NIM.

Mesozoic rifting structures are very well exposed in the NW of the WIM, in the Galicia Bank region. However, further south, the nature of the highly 